\title{
Efficient and Selective Transport of Silver(I) Cation Across a Bulk Dichloromethane Membrane Using 1,13-Bis(8-quinolyl)-1,4,7,10,13-pentaoxatridecane as a Carrier
}

\author{
G. H. ROUNAGHI ${ }^{*}$ AND A. GHAEMI ${ }^{\#}$ \\ *Department of Chemistry, Faculty of Sciences, Ferdowsi University of Mashhad, Mashhad, \\ Iran \\ \#Department of Chemistry, Science and Research Branch, Islamic Azad University, \\ Khouzestan, Iran \\ ghrounaghi@yahoo.com \\ arezooghaemi@yahoo.com
}

Received 10 October 2011; Accepted 15 January 2012

\begin{abstract}
Bis(8-quinolyl)-1,4,7,10,13-pentaoxatridecane (Kryptofix 5) was used as a highly efficient carrier for the transport of silver(I) cation through a dichloromethane (DCM) bulk liquid membrane. In order to achieve the highest transport efficiency of $\mathrm{Ag}^{+}$cation across the bulk liquid membrane system, the influence of different parameters was studied. These include: the nature of various organic solvents as liquid membrane phase, concentration of the carrier in the membrane phase, concentration of picric acid as counter anion in the source phase, type of various stripping agents in the receiving phase, concentration of thiosulfate anion $\left(\mathrm{S}_{2} \mathrm{O}_{3}^{2-}\right)$ as a suitable stripping agent, $\mathrm{pH}$ of the source and receiving phases, volume of the receiving phase and equilibrium time of transport which were optimized. In the optimum procedure conditions, the transport of a $3 \times 10^{-4} \mathrm{M}$ solution of silver(I) cation was observed $(88.03 \pm 0.82 \%)$ after 4 hours. The selectivity of $\mathrm{Ag}^{+}$transport from aqueous solutions containing equimolar concentration of other metal cations such as $\mathrm{Pb}^{2+}, \mathrm{Co}^{2+}, \mathrm{Zn}^{2+}, \mathrm{Cd}^{2+}, \mathrm{Cu}^{2+}$ and $\mathrm{Fe}^{3+}$ was also investigated.
\end{abstract}

Key words: Silver (I) cation, Kryptofix 5, Dichloromethane, Bulk liquid membrane transport.

\section{Introduction}

Silver is used widely in the production of coins, jewellery, tableware and alloys, and in the manufacture of electrical apparatus, mirrors and chemicals for photographic processes. Additionally, it is used in the production of dental amalgams and burn creams as silver sulfadiazine cream (SSD), due to its antibacterial properties [1-3]. Silver metal is practically non toxic, acute toxicity by ingestion is low. However, chronic absorption may cause "Argyria" a blue/grey discoloration of various tissues, ocular injury, leukopenia, and toxicity 
in kidney, liver, and neurologic tissues [4]. Thus, the determination of silver in various media is of importance.

Membrane extraction is a promising technique for removal of valuable metal ions from diluted solutions [5,6]. A liquid membrane is a layer of an organic solvent separating two aqueous solutions. Compounds, promoting the transport of substances from one aqueous solution to another, may be dissolved in the organic phase. Liquid membranes have a lot of advantages over traditional solvent extraction, such as low capital and operating costs, combination of extraction and stripping processes into a single stage and small amounts of extractants. Liquid membranes can be classified as bulk, supported and emulsion membranes. Bulk liquid membranes are relatively thick $(0.01-1 \mathrm{~cm})$ and stable. The main issue for all types of supported liquid membranes is short lifetime of these membranes. Emulsion liquid membrane process is much more complex than that of the bulk liquid membrane.

Nowadays many compounds have been designed and synthesized to form remarkably stable and selective complexes with heavy metal ions such as schiffbases [7], podands [8], cyclams [9] and calixarenes [10]. Among them cryptands and crown ethers are of special interest as they exhibit extremely high affinities toward heavy metal ions such as $\mathrm{Ag}^{+}, \mathrm{Hg}^{2+}$ and $\mathrm{Pb}^{2+}$ [11-13]. Their selectivities and coordination abilities with transition metal ions depend on ring cavity size, ligand rigidity, the nature of donor atoms and their disposition [14]. In recent years, many crown ethers have been synthesized and successfully utilized for highly selective binding with heavy metal cations in diversal processes such as ion transports through artificial and natural membranes, liquid-liquid phase-transfer reactions and isotope separations [15-17].

In our early experiments, we tested the competitive transport of $\mathrm{Co}^{2+}, \mathrm{Fe}^{3+}, \mathrm{Cd}^{2+}, \mathrm{Cu}^{2+}$, $\mathrm{Zn}^{2+}, \mathrm{Ag}^{+}$and $\mathrm{Pb}^{2+}$ metal cations from an aqueous source phase into an aqueous receiving phase through $\mathrm{NB}, \mathrm{CHCl}_{3}, \mathrm{DCM}$ and 1,2-DCE organic solvents as liquid membranes containing kryptofix 5 ligand at ambient temperature [18]. The obtained results show that this ligand is a highly selective ionophore for $\mathrm{Ag}^{+}$cation among the other metal cations and the sequence of transport efficiency for $\mathrm{Ag}^{+}$cation in these organic solvents was found to be: $\mathrm{DCM}>\mathrm{CHCl}_{3}>1,2-\mathrm{DCE}>\mathrm{NB}$.

In this work, we employed kryptofix 5 as an excellent specific ion carrier for the highly efficient and selective transport of $\mathrm{Ag}^{+}$metal cation through a bulk dichloromethane membrane. It has been demonstrated that such a system is capable of transporting cations against a proton gradient, as driving force. The potential of this ligand to complex and transport of $\mathrm{Ag}^{+}$metal cation was verified and the influence of effective parameters was optimized.

\section{Experimental}

\section{Reagents and solvents}

1,13-Bis(8-quinolyl)-1,4,7,10,13-pentaoxatridecane (Kryptofix 5) (Scheme 1), silver(I) nitrate, iron(III) nitrate, cadmium(II) nitrate, zinc(II) nitrate, copper(II) nitrate, cobalt(II) nitrate, lead(II) nitrate, sodium acetate, acetic acid, sodium hydroxide, formic acid, picric acid, sodium thiosulfate, sodium sulfite, sodium thiocyanate, sodium pyrophosphate, EDTA and thiourea all purchased from Merck and used without further purification. Dichloromethane (DCM), chloroform $\left(\mathrm{CHCl}_{3}\right)$, nitrobenzene (NB) and 1,2-dichloroethane (1,2-DCE) (all from Merck) were used with the highest purity. All aqueous solutions were prepared using double distilled deionized water. 
<smiles>c1cnc2c(OCCOCCOCCOCCOc3cccc4cccnc34)cccc2c1</smiles>

Scheme 1. Structure of 1,13-bis(8-quinolyl)-1,4,7,10,13-pentaoxatridecane (Kryptofix 5).

\section{Apparatus}

The determination of silver(I) content was carried out by a Shimadzu AA-670 atomic absorption spectrometer (AAS) equipped with an Ag-hallow cathode lamp. The $\mathrm{pH}$ measurements were made with a Metrohm 692 pH-meter using a combined glass electrode. A bulk liquid membrane cell was used in all transport experiments (Scheme 2).

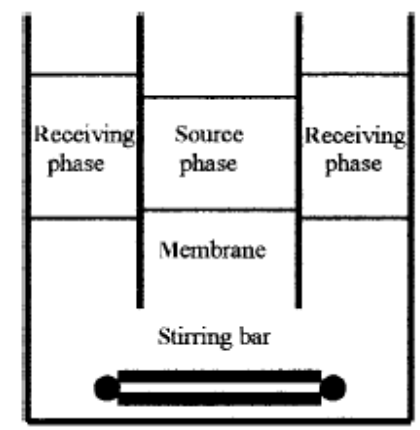

Scheme 2. Representation of the bulk type liquid membrane cell used.

\section{Procedure}

Bulk liquid membrane (BLM) transport measurements were performed at ambient temperature in a cylindrical glass cell (inside diameter $5 \mathrm{~cm}$ ) holding a glass tube (inside diameter $2 \mathrm{~cm}$ ), thus separating the two aqueous phases. The inner aqueous phase (source phase, SP) contained silver(I) nitrate $\left(10 \mathrm{ml}, 3.0 \times 10^{-4} \mathrm{M}\right)$ and picric acid $\left(3.0 \times 10^{-3} \mathrm{M}\right)$. The outer aqueous phase (receiving phase, $\mathrm{RP}$ ) was a $\mathrm{Na}_{2} \mathrm{~S}_{2} \mathrm{O}_{3}$ solution $\left(5 \mathrm{ml}, 1.0 \times 10^{-3} \mathrm{M}\right)$. The transport process was maintained by the buffering the aqueous source and receiving phases. The membrane phase (MP) contained $50 \mathrm{ml}$ of $1.0 \times 10^{-3} \mathrm{M}$ kryptofix 5 as carrier in organic solvent. The membrane phase was magnetically stirred by a Teflon-coated magnetic bar. Under these conditions, not only the mixing process is perfect, but also the interfaces between the organic membrane and the two aqueous phases remained flat and were well defined. Determination of the silver(I) concentration in both aqueous phases was carried out by AAS. The data points reported are averages of at least three replicate measurements.

\section{Results and discussion}

Effect of organic solvent as membrane phase

The nature of the membrane solvent is one of the main factors in establishing transport efficiency. Several parameters whose values depend on the membrane solvent can affect the 
transport of metal cations through bulk liquid membranes. The physical and chemical properties of solvents are closely related to their structures and play important roles in solute-solvent and solute-solute interactions in solutions. The organic solvent which should be immiscible with water and non-volatile must have a suitable polarity related to an optimal value of the association constant of the complex. A solvent of low viscosity must be chosen to obtain the highest rate of transport possible in a particular system $[19,20]$.

In the present work, we have examined the influence of some organic solvents as membrane phase. The data for selective transport of $\mathrm{Ag}^{+}$cation from an aqueous source phase through DCM, 1,2-DCE, $\mathrm{CHCl}_{3}$ and $\mathrm{NB}$ organic membranes containing kryptofix 5 at ambient temperature is given in Table 1 . As is seen, the transport efficiency of $\mathrm{Ag}^{+}$cation by kryptofix 5 as carrier is varied in order: $\mathrm{DCM}>\mathrm{CHCl}_{3}>1,2-\mathrm{DCE}>\mathrm{NB}$. According to the physicochemical properties of the solvents, these results may be attributed to the lower viscosity of DCM $(\eta=0.39)$ which leads to increase the rate of ion transfer in this organic solvent compared to the other three organic solvents. Moreover, the low donor number (DN) of dichloromethane $(\mathrm{DN}=1)$ results in decreasing the competition between the solvent and the ligand molecules for the metal cation which leads to increase the stability of the complex formed between the $\mathrm{Ag}^{+}$cation and the ligand and, therefore, increasing the transport rate of silver(I) cation in this organic solvent. In addition, the lower dielectric constant of DCM $(\varepsilon=$ 8.93) than those of 1,2-DCE $(\varepsilon=10.66)$ and $\mathrm{NB}(\varepsilon=34.80)$, may aid the ion-pair formation in DCM which results in a better transfer rate in this membrane system.

Table 1. Effect of the organic solvent on $\mathrm{Ag}^{+}$cation transport ${ }^{\mathrm{a}}$.

\begin{tabular}{ccc}
\hline Organic solvent & Transported into receiving phase (\%) & Remaining in source phase (\%) \\
\hline $\mathrm{DCM}$ & 88.05 & 1.36 \\
$\mathrm{CHCl}_{3}$ & 64.51 & 15.43 \\
$1,2-\mathrm{DCE}$ & 6.17 & 26.92 \\
$\mathrm{NB}$ & 4.84 & 54.72 \\
\hline
\end{tabular}

${ }^{\mathrm{a}}$ Experimental conditions: source phase, $10 \mathrm{ml}$ of $3.0 \times 10^{-4} \mathrm{M} \mathrm{Ag}^{+}$cation and $3.0 \times 10^{-3} \mathrm{M}$ picric acid at $\mathrm{pH} 4$; liquid membrane phase, $50 \mathrm{ml}$ of $1.0 \times 10^{-3} \mathrm{M}$ carrier in different organic solvents; receiving phase, $5 \mathrm{ml}$ of $1.0 \times 10^{-3} \mathrm{M} \mathrm{S}_{2} \mathrm{O}_{3}{ }^{2-}$ at $\mathrm{pH} 3$; time of transport, 4 hours.

\section{Effect of carrier concentration in the membrane phase}

As expected, it has been found that the nature of the ligand used as a carrier in the organic membrane phase has a significant effect on the efficiency and selectivity of metal cation transport $[21,24]$.

In our early experiments, we tested the kryptofix 5 ability to transport of $\mathrm{Co}^{2+}, \mathrm{Fe}^{3+}, \mathrm{Cd}^{2+}$, $\mathrm{Cu}^{2+}, \mathrm{Zn}^{2+}, \mathrm{Ag}^{+}$and $\mathrm{Pb}^{2+}$ metal cations from an aqueous source phase into the aqueous receiving phase through DCM, 1,2-DCE, $\mathrm{CHCl}_{3}$, and $\mathrm{NB}$ organic solvents as membrane. The obtained results showed that this ligand is a highly selective ionophore for $\mathrm{Ag}^{+}$cation among the other metal cations. The attachment of phenyl groups to this ligand increases its lipophilicity, thus increasing its solubility and effectively trapping it in the organic phase into one or both of aqueous phases. In addition, the interaction of $\pi$-electron system presents in aromatic rings with the silver(I) cation may be effective on complexation process between this metal cation and the ligand $[25,26]$. Therefore, it seems that silver(I) cation gets self encapsulated by the ligand and hence shows maximum transport efficiency.

The effect of concentration of the ligand in the organic membrane phase on the transport efficiency of $\mathrm{Ag}^{+}$metal cation was studied (Figure 1). As is obvious from this Figure, while 
the transport of $\mathrm{Ag}^{+}$cation in the absence of the carrier is very low, but, the transport efficiency of this cation increases sharply with increasing the concentration of carrier in the membrane phase. The maximum transport occurs at $1.0 \times 10^{-3} \mathrm{M}$ of the carrier.

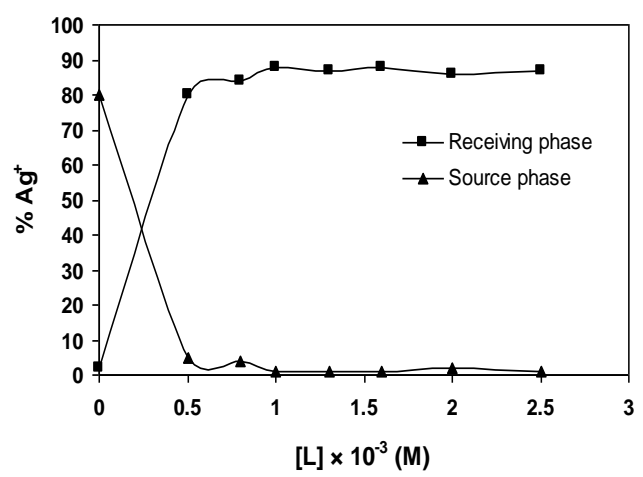

Figure 1: Effect of carrier concentration on $\mathrm{Ag}^{+}$cation transport. Experimental conditions: source phase, $10 \mathrm{ml}$ of $3.0 \times 10^{-4} \mathrm{M} \mathrm{Ag}^{+}$cation and $3.0 \times 10^{-3} \mathrm{M}$ picric acid at $\mathrm{pH} 4$; liquid membrane phase, $50 \mathrm{ml}$ of varying concentration of carrier in DCM; receiving phase, $5 \mathrm{ml}$ of $1.0 \times 10^{-3} \mathrm{M} \mathrm{S}_{2} \mathrm{O}_{3}{ }^{2-}$ at $\mathrm{pH} 3$; time of transport, 4 hours.

\section{Effect of picric acid in the source phase}

In preliminary experiments, it was found that the nitrate ion is not a suitable counter anion to accompany the (ligand- $\mathrm{Ag}^{+}$) complex into the organic phase, only $23.48 \%$ of $\mathrm{Ag}^{+}$cation was transported into the receiving phase. However, addition of picric acid to the source phase increased the $\mathrm{Ag}^{+}$cation transport. The influence of the concentration of picric acid in the source phase on the silver(I) cation transport was investigated and the results are shown in Figure 2. The optimum concentration of picric acid was found to be $3.0 \times 10^{-3} \mathrm{M}$. As seen from this Figure, the efficiency of $\mathrm{Ag}^{+}$cation transport increases with increasing picric acid concentration up to $3.0 \times 10^{-3} \mathrm{M}$, but further increase in the concentration of picric acid caused a pronounced decrease in the transport efficiency of $\mathrm{Ag}^{+}$cation. This behavior maybe due to the competition of picric acid with $\mathrm{Ag}^{+}$cation for transport process. Similar behavior has been observed for selective transport of silver(I) cation through liquid membranes [27].

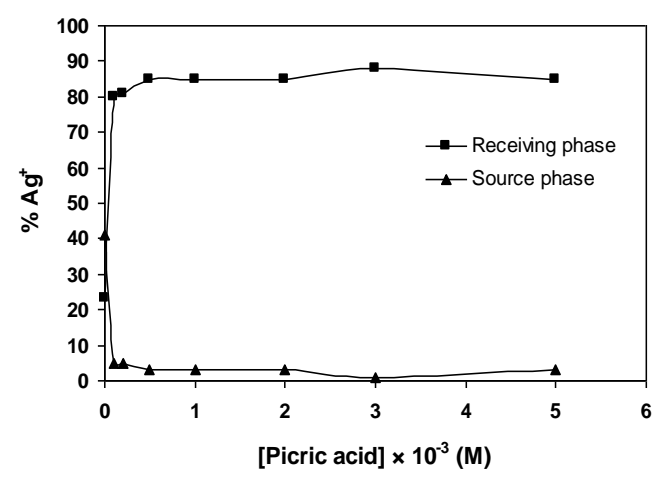

Figure 2. Effect of picric acid concentration on $\mathrm{Ag}^{+}$cation transport. Experimental conditions: source phase, $10 \mathrm{ml}$ of $3.0 \times 10^{-4} \mathrm{M} \mathrm{Ag}^{+}$cation and varying concentration of picric acid at $\mathrm{pH} 4$; liquid membrane phase, $50 \mathrm{ml}$ of $1.0 \times 10^{-3} \mathrm{M}$ carrier in DCM; receiving phase, $5 \mathrm{ml}$ of $1.0 \times 10^{-3} \mathrm{M} \mathrm{S}_{2} \mathrm{O}_{3}{ }^{2-}$ at $\mathrm{pH} 3$; time of transport, 4 hours. 
Effect of stripping agent type and its concentration in the receiving phase

Permeability of the membrane system for $\mathrm{Ag}^{+}$cation was found to be largely dependent on the nature and concentration of stripping ligand used in the receiving phase. As is evident from Table 2, the use of thiosulfate $\left(\mathrm{S}_{2} \mathrm{O}_{3}{ }^{2-}\right)$ as stripping agent in the receiving phase caused a rather large increase in the efficiency of $\mathrm{Ag}^{+}$cation transport. While the presence of other stripping agents such as $\mathrm{SO}_{3}{ }^{2-}, \mathrm{SCN}^{-}, \mathrm{P}_{2} \mathrm{O}_{7}{ }^{4-}$, EDTA and thiourea results in diminished transport efficiency. The optimum concentration of thiosulfate anion in the receiving phase was investigated (Figure 3) and it was found to be $1.0 \times 10^{-3} \mathrm{M}$. It is worthily to note that in the absence of the stripping agent on the receiving phase, the silver(I) cation transports only $11.17 \%$ into the receiving phase.

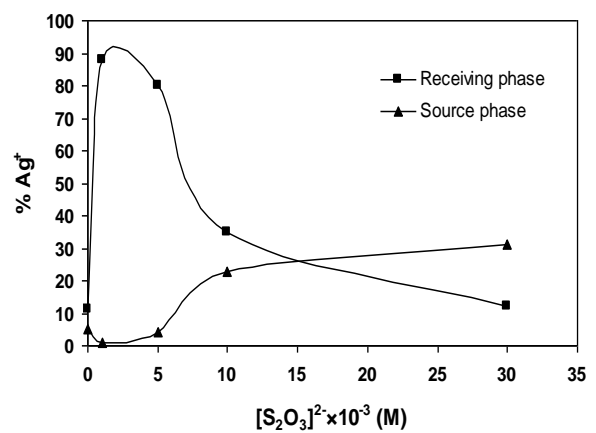

Figure 3. Effect of thiosulfate anion $\left(\mathrm{S}_{2} \mathrm{O}_{3}{ }^{2-}\right)$ concentration in the receiving phase on $\mathrm{Ag}^{+}$ cation transport. Experimental conditions: source phase, $10 \mathrm{ml}$ of $3.0 \times 10^{-4} \mathrm{M} \mathrm{Ag}^{+}$cation and $3.0 \times 10^{-3} \mathrm{M}$ picric acid at $\mathrm{pH} 4$; liquid membrane phase, $50 \mathrm{ml}$ of $1.0 \times 10^{-3} \mathrm{M}$ carrier in DCM; receiving phase, $5 \mathrm{ml}$ of varying concentration of $\mathrm{S}_{2} \mathrm{O}_{3}{ }^{2-}$ at $\mathrm{pH} 3$; time of transport, 4 hours.

Table 2. Effect of different stripping agents present in the receiving phase on $\mathrm{Ag}^{+}$cation transport ${ }^{\mathrm{a}}$.

\begin{tabular}{ccc}
\hline $\begin{array}{c}\text { Nature of } \\
\text { stripping agent }\end{array}$ & Transported into receiving phase (\%) & Remaining in source phase (\%) \\
\hline $\mathrm{S}_{2} \mathrm{O}_{3}{ }^{2-}$ & 88.64 & 1.21 \\
$\mathrm{SO}_{3}{ }^{2-}$ & $-{ }^{\mathrm{b}}$ & 5.43 \\
$\mathrm{SCN}^{-}$ & - & 70.33 \\
$\mathrm{P}_{2} \mathrm{O}_{7}^{4-}$ & - & 26.70 \\
$\mathrm{EDTA}^{4-}$ & - & 25.34 \\
Thiourea & 72.04 & 20.50
\end{tabular}

${ }^{\mathrm{a}}$ Experimental conditions: source phase, $10 \mathrm{ml}$ of $3.0 \times 10^{-4} \mathrm{M} \mathrm{Ag}^{+}$cation and $3.0 \times 10^{-3} \mathrm{M}$ picric acid at $\mathrm{pH} 4$; liquid membrane phase, $50 \mathrm{ml}$ of $1.0 \times 10^{-3} \mathrm{M}$ carrier in DCM; receiving phase, $5 \mathrm{ml}$ of $1.0 \times 10^{-3} \mathrm{M}$ of different stripping agents at $\mathrm{pH} 3$; time of transport, 4 hours.

${ }^{\mathrm{b}}$ The hyphenated symbols mean that the values are about zero. 


\section{Effect of $p H$}

The influence of $\mathrm{pH}$ of the source phase and receiving phase on the transport efficiency of $\mathrm{Ag}^{+}$cation was studied and the results are shown in Figures 4 and 5, respectively. As is evident from these Figures, the maximum silver(I) cation transport occurs at $\mathrm{pH} 4$ of the source phase and $\mathrm{pH} 3$ of the receiving phase.

\section{Effect of receiving phase volume}

The influence of the receiving phase volume on the transport efficiency of silver(I) cation was investigated (Figure 6). As is obvious in this Figure, the optimum volume of the receiving phase is $5 \mathrm{ml}$. Therefore, the separation and preconcentration $\mathrm{of}^{\mathrm{Ag}^{+}}$cation occur during this technique.

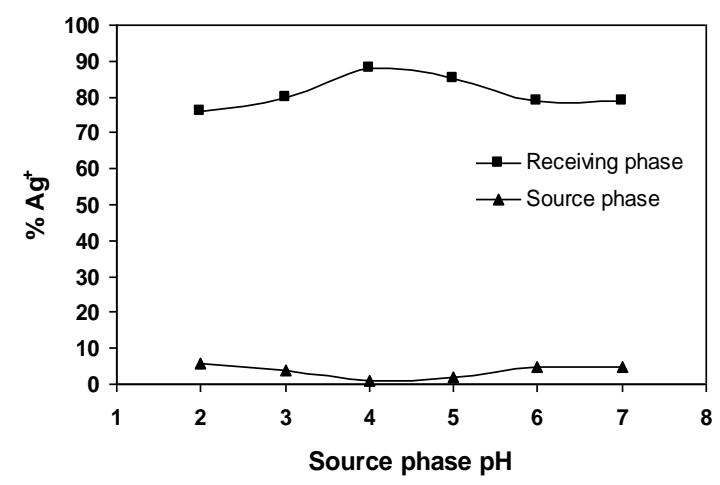

Figure 4. Effect of $\mathrm{pH}$ in source phase on $\mathrm{Ag}^{+}$cation transport. Experimental conditions: source phase, $10 \mathrm{ml}$ of $3.0 \times 10^{-4} \mathrm{M} \mathrm{Ag}^{+}$cation and $3.0 \times 10^{-3} \mathrm{M}$ picric acid with various $\mathrm{pH}$; liquid membrane phase, $50 \mathrm{ml}$ of $1.0 \times 10^{-3} \mathrm{M}$ carrier in DCM; receiving phase, $5 \mathrm{ml}$ of $1.0 \times 10^{-3} \mathrm{M} \mathrm{S}_{2} \mathrm{O}_{3}{ }^{2-}$ at $\mathrm{pH} 3$; time of transport, 4 hours.

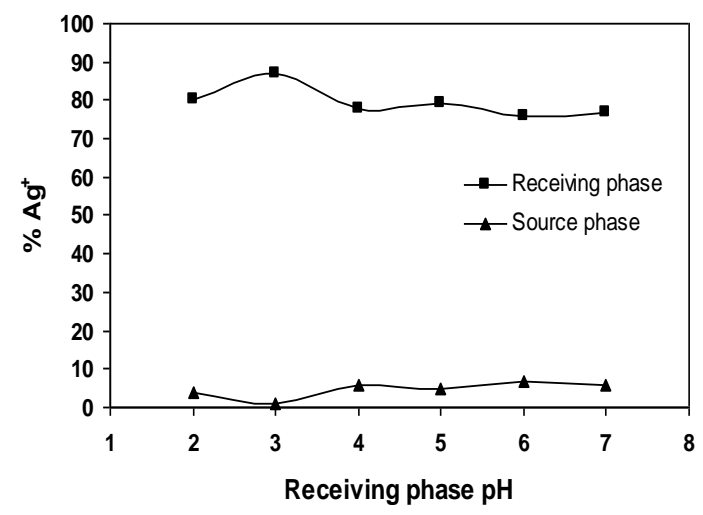

Figure 5. Effect of $\mathrm{pH}$ in receiving phase on $\mathrm{Ag}^{+}$cation transport. Experimental conditions: source phase, $10 \mathrm{ml}$ of $3.0 \times 10^{-4} \mathrm{M} \mathrm{Ag}^{+}$cation and $3.0 \times 10^{-3} \mathrm{M}$ picric acid at $\mathrm{pH} 4$; liquid membrane phase, $50 \mathrm{ml}$ of $1.0 \times 10^{-3} \mathrm{M}$ carrier in DCM; receiving phase, $5 \mathrm{ml}$ of $1.0 \times 10^{-3} \mathrm{M}$ $\mathrm{S}_{2} \mathrm{O}_{3}{ }^{2-}$ with various $\mathrm{pH}$; time of transport, 4 hours. 


\section{Effect of time}

A series of cells were designed for the transport of $\mathrm{Ag}^{+}$cation and each cell examined after a certain time of stirring. Figure 7 shows the time dependence of $\mathrm{Ag}^{+}$cation transport through the liquid membrane under the optimal experimental conditions. It is obvious that the transport of this cation into the receiving phase increases with time. According to the results obtained in this study, it was confirmed that about $88.52 \%$ of $\mathrm{Ag}^{+}$cation was transported from the source phase into the receiving phase after 4 hours.

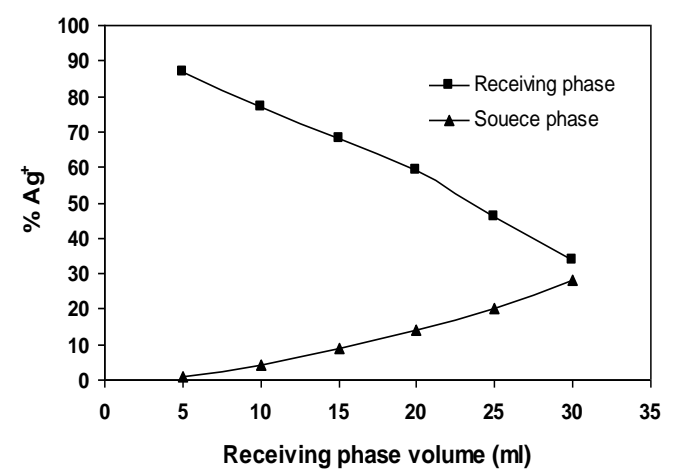

Figure 6. Effect of receiving phase volume on $\mathrm{Ag}^{+}$caion transport. Experimental conditions: source phase, $10 \mathrm{ml}$ of $3.0 \times 10^{-4} \mathrm{M} \mathrm{Ag}^{+}$cation and $3.0 \times 10^{-3} \mathrm{M}$ picric acid at $\mathrm{pH}$ 4; liquid membrane phase, $50 \mathrm{ml}$ of $1.0 \times 10^{-3} \mathrm{M}$ carrier in DCM; receiving phase, varying volume of $1.0 \times 10^{-3} \mathrm{M} \mathrm{S}_{2} \mathrm{O}_{3}{ }^{2-}$ at $\mathrm{pH} 3$; time of transport, 4 hours.

\section{Reproducibility of the bulk liquid membrane transport}

The reproducibility of $\mathrm{Ag}^{+}$cation transport was investigated and the percent of $\mathrm{Ag}^{+}$cation transported after $4 \mathrm{~h}$ from six replicate measurements was found to be: $88.03 \pm 0.82 \%$.

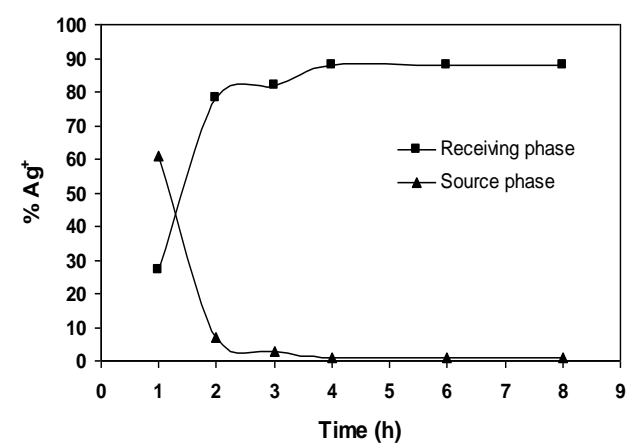

Figure 7. Effect of time on $\mathrm{Ag}^{+}$cation transport. Experimental conditions: source phase, 10 $\mathrm{ml}$ of $3.0 \times 10^{-4} \mathrm{M} \mathrm{Ag}^{+}$cation and $3.0 \times 10^{-3} \mathrm{M}$ picric acid at $\mathrm{pH} 4$; liquid membrane phase, 50 $\mathrm{ml}$ of $1.0 \times 10^{-3} \mathrm{M}$ carrier in DCM; receiving phase, $5 \mathrm{ml}$ of $1.0 \times 10^{-3} \mathrm{M} \mathrm{S}_{2} \mathrm{O}_{3}{ }^{2-}$ at $\mathrm{pH} 3$.

\section{Transport selectivity}

We also investigated the effect of various metal cations such as $\mathrm{Pb}^{2+}, \mathrm{Co}^{2+}, \mathrm{Zn}^{2+}, \mathrm{Cd}^{2+}, \mathrm{Cu}^{2+}$ and $\mathrm{Fe}^{3+}$ on the selectivity of liquid membrane for $\mathrm{Ag}^{+}$cation. The results are given in Table 
3. As is seen in this Table, with the exception of $\mathrm{Pb}^{2+}$ cation, no interfering effect was observed by other metal cations in transport efficiency of silver(I) cation.

Table 3. Amount of cations transported from various cation mixtures through DCM membrane $^{\mathrm{a}}$

\begin{tabular}{|c|c|c|}
\hline Mixture & $\begin{array}{c}\text { Transported into receiving } \\
\text { phase }(\%)\end{array}$ & $\begin{array}{c}\text { Remaining in source phase } \\
(\%)\end{array}$ \\
\hline Mixture 1 & 73.59 & 5.22 \\
\hline $\mathrm{Ag}^{+}$ & 11.18 & 75.50 \\
\hline $\mathrm{Pb}^{2+}$ & $-^{\mathrm{b}}$ & 80.95 \\
\hline \multicolumn{3}{|l|}{$\mathrm{Co}^{2+}$} \\
\hline Mixture 2 & 75.30 & 4.41 \\
\hline \multicolumn{3}{|l|}{$\mathrm{Ag}^{+}$} \\
\hline $\mathrm{Zn}^{2+}$ & 3.68 & 30.44 \\
\hline \multicolumn{3}{|l|}{$\mathrm{Cd}^{2+}$} \\
\hline & 1.15 & 26.14 \\
\hline Mixture 3 & 73.77 & 4.62 \\
\hline \multicolumn{3}{|l|}{$\mathrm{Ag}^{+}$} \\
\hline $\mathrm{Cu}^{2+}$ & 2.30 & 71.09 \\
\hline $\mathrm{Fe}^{3+}$ & - & 60.23 \\
\hline
\end{tabular}

${ }^{\mathrm{a}}$ Experimental conditions: source phase, $10 \mathrm{ml}$ of $3.0 \times 10^{-4} \mathrm{M}$ various cation mixtures and $3.0 \times 10^{-3} \mathrm{M}$ picric acid at $\mathrm{pH} 4$; liquid membrane phase, $50 \mathrm{ml}$ of $1.0 \times 10^{-3} \mathrm{M}$ carrier in DCM; receiving phase, $5 \mathrm{ml}$ of $1.0 \times 10^{-3} \mathrm{M} \mathrm{S}_{2} \mathrm{O}_{3}{ }^{2-}$ at $\mathrm{pH} 3$; time of transport, 4 hours.

${ }^{\mathrm{b}}$ The hyphenated symbols mean that the values are about zero.

\section{Recommended mechanism}

The recommended mechanism for the transport of $\mathrm{Ag}^{+}$cation through bulk liquid membrane, which operated in this study, is shown in Scheme 3. Movement of the charge species through the hydrophobic organic membrane is accomplished by the presence of host ligand, ion paired with picrate as a suitable counter anion. The picrate ion not only neutralizes the charged (ligand- $\mathrm{Ag}^{+}$) complex, but also induces a more lipophilic character to the $\mathrm{Ag}^{+}$complex so that it can be readily extracted into the membrane phase. After complexation of $\mathrm{Ag}^{+}$cation with the carrier on the source side of the membrane, the 
complex diffuses down its concentration gradient. On the receiving side of the membrane, the metal cation is released into the receiving phase via formation of a ternary complex (ligand- $\mathrm{Ag}^{+}-\mathrm{S}_{2} \mathrm{O}_{3}{ }^{2-}$ ). Then the free carrier diffuses back across the membrane and cycle starts again. The net result is the transport of $\mathrm{Ag}^{+}$cation from the aqueous source phase into the aqueous receiving phase across the bulk liquid membrane.
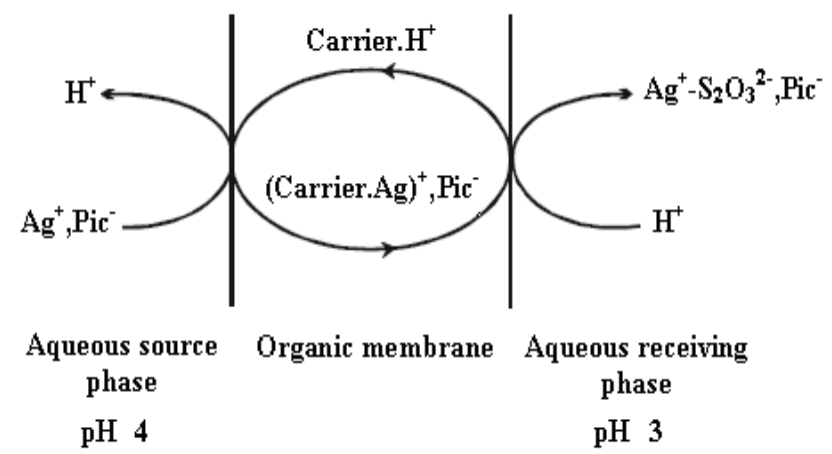

Scheme 3. Transport mechanism of $\mathrm{Ag}^{+}$cation through BLM process.

\section{Conclusion}

The present study demonstrates that kryptofix 5 is an excellent carrier for selective and efficient transport of $\mathrm{Ag}^{+}$cation through DCM bulk liquid membrane containing this carrier. Addition of picrate ion as a suitable counter anion to the source phase increased the $\mathrm{Ag}^{+}$ cation transport efficiency. The presence of thiosulfate ion $\left(\mathrm{S}_{2} \mathrm{O}_{3}{ }^{2-}\right)$ as cation acceptor in the receiving phase greatly increases the efficiency of transport of silver(I) cation without affecting the selectivity. The choice of the appropriate counter anions in the source and receiving solutions and the concentration of the neutral carrier in the membrane phase is particularly important in determining the efficiency and selectivity of the transport process. This study also demonstrates the usefulness of the liquid membrane technique for making it possible to combine extraction and stripping operations in a single process. In conclusion, therefore, the above system, which is specific for $\mathrm{Ag}^{+}$cation, is a potential candidate for practical use in silver(I) cation separation, especially as it has the advantages of high precision, efficiency, selectivity and simplicity.

\section{Acknowledgement}

The authors acknowledge the support of this work by Ferdowsi University of Mashhad, Mashhad, Iran.

\section{References}

1. Carr H S, Wlodkowski T J and Rosenkranz H S, Antimicrob. Agents Chemother. 1973, 4, 585.

2. Silver S, Phung Le T and Silver G, J. Ind. Microbiol. Biotechnol. 2006, 33, 627.

3. Clarke A M, Med. J. Aust. 1975, 1, 413. 
4. Wan A T, Conyers R A, Coombs C J and Masterton P, Clin. Chem. 1991, 37, 1683.

5. Araki $\mathrm{T}$ and Tsukube $\mathrm{H}$ (Eds.): Liquid Membranes: Chemical Applications; CRC Press, Boca Raton, Florida, 1990.

6. Cox M, Liquid-Liquid Extraction and Liquid Membranes in the Perspective of the Twenty-first Century, in: Aguilar M and Cortina J L (Eds.): Solvent Extraction and Liquid Membranes: Fundamentals and Applications in New Materials; CRC Press, New York, pp. 2-18, 2006.

7. Borisova N E, Reshetova M D and Ustynyuk Y A, Chem. Rev. 2007, 107, 46.

8. Bünzli J C G and Piguet C, Chem. Rev. 2002, 102, 1897.

9. Nolan E M and Lippard S J, Chem. Rev. 2008, 108, 3443.

10. Homden D M and Redshaw C, Chem. Rev. 2008, 108, 5086.

11. Gholivand M B, Rahimi Nasrabadi M, Ganjali M R and Salavati Niasari M, Talanta 2007, 73, 553.

12. Li X G, Ma X L and Huang M R, Talanta 2009, 78, 498.

13. Gupta V K, Singh A K, Khayat M A and Gupta B, Anal. Chim. Acta 2007, 590, 81.

14. Fernández Fernández M C, Bastida R, Macías A, Pérez Lourido P and Valencia L, Inorg. Chim. Acta 2009, 362, 471.

15. Ocak M, Alp H, Kantekin H, Karadeniz H and Ocak Ü, J. Incl. Phenom. Macrocycl. Chem. 2008, 60, 17.

16. Cui J and Zhang L, J. Hazard. Mater. 2008, 158, 228.

17. Domash V I, Sharpio T P, Zabreiko S A and Sosnovskaya T F, Russ. J. Bioorg. Chem. 2008, 34, 318.

18. Rounaghi G H, Ghaemi A and Chamsaz M, Arabian J. Chem. 2011 (Article in press).

19. McBride D W, Izatt R M, Lamb J D and Christensen J J, in: Atwood J L, Davies J E and MacNical D D (Eds.): Inclusion Compounds, Physical Properties and Applications; Academic Press, New York, 3, 598, 1984.

20. Izatt R M, Bruening R L, Clark G A, Lamb J D and Christensen J J, J. Membr. Sci. 1986, 28, 77.

21. Kazemi S Y and Shamsipur M, Sep. Purif. Technol. 1999, 17, 181.

22. Rounaghi G H and Kazemi M S, J. Incl. Phenom. Macrocycl. Chem. 2006, 55, 347.

23. Rounaghi G H, Hosseiny M S and Chamsaz M, J. Incl. Phenom. Macrocycl. Chem. 2011, 69, 221.

24. Nezhadali A, Hakimi M and Heydari M, E-Journal of Chemistry 2008, 5, 52.

25. Rounaghi G H, Khoshnood R S and Arbab Zavvar M H, J. Incl. Phenom. Macrocycl. Chem. 2006, 54, 247.

26. Rounaghi G H, Zavar M H and Mohammad Zadeh Kakhki R, Russ. J. Coord. Chem. 2008, 34, 167.

27. Shamsipur M, Azimi G, Mashhadizadeh M H and Madaeni S S, Anal. Sci. 2001, 17, 491. 


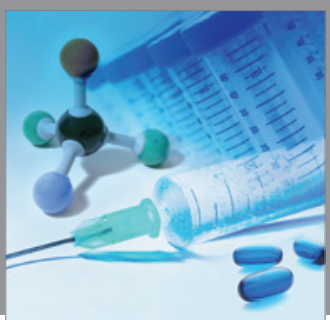

International Journal of

Medicinal Chemistry

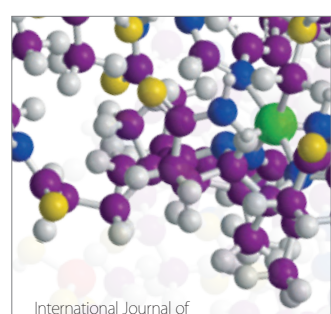

Carbohydrate Chemistry

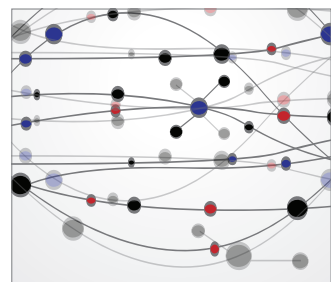

The Scientific World Journal
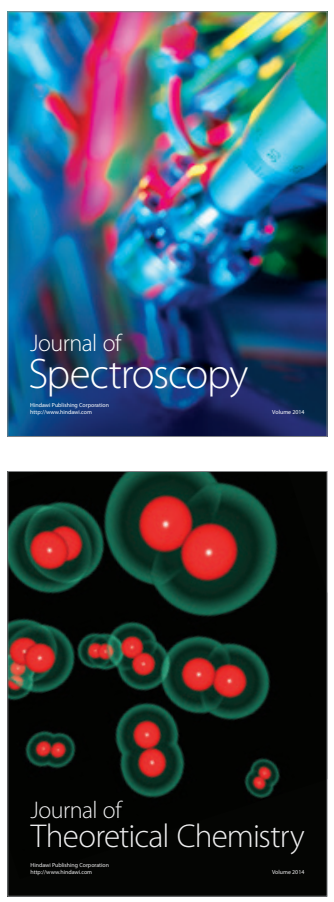
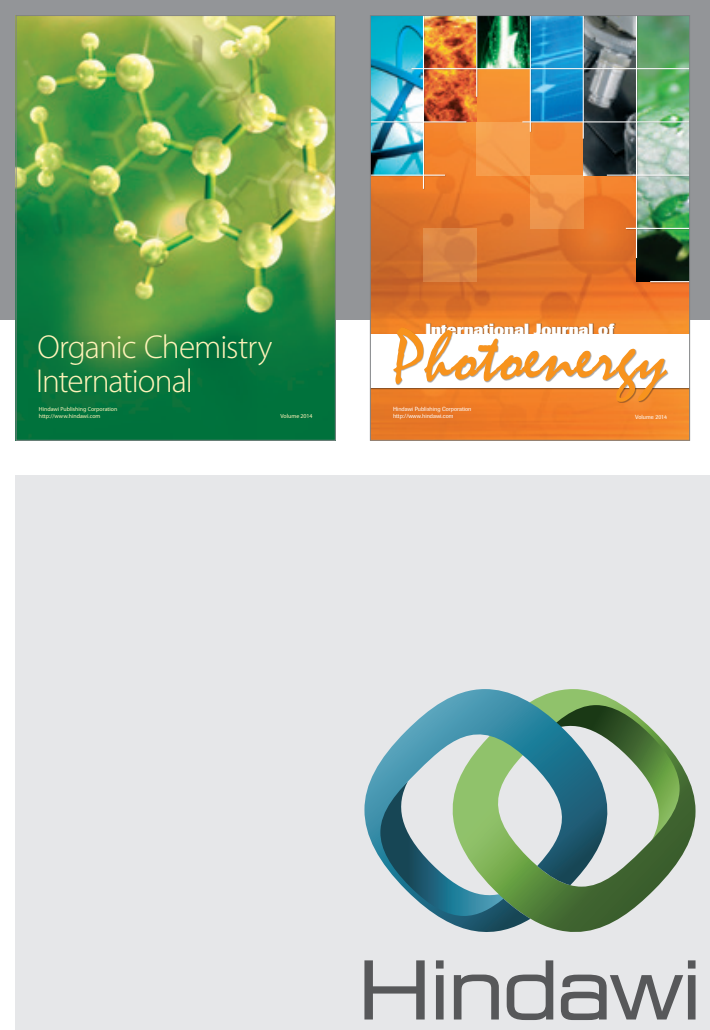

Submit your manuscripts at

http://www.hindawi.com
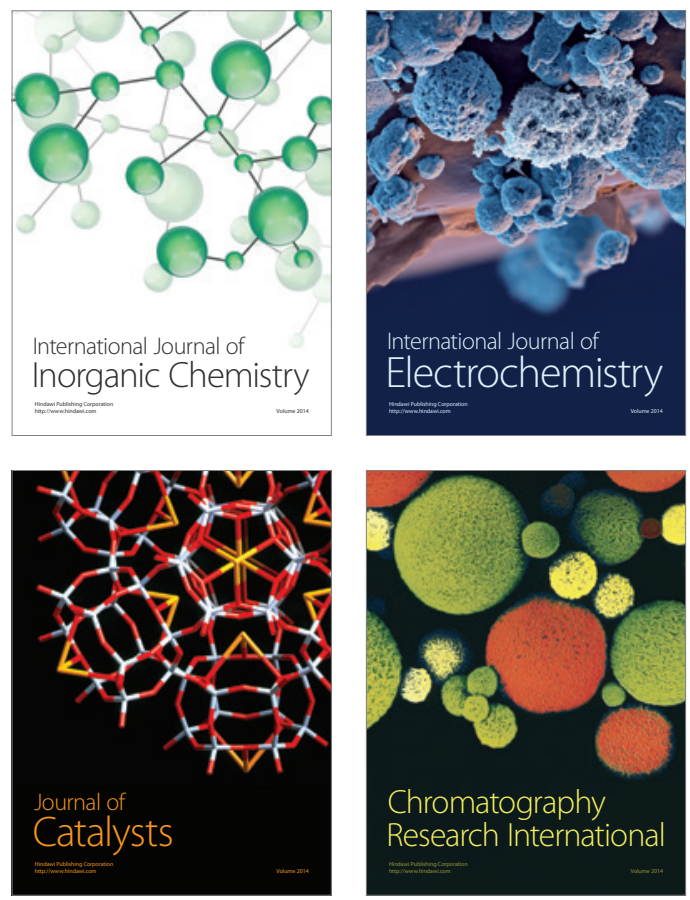
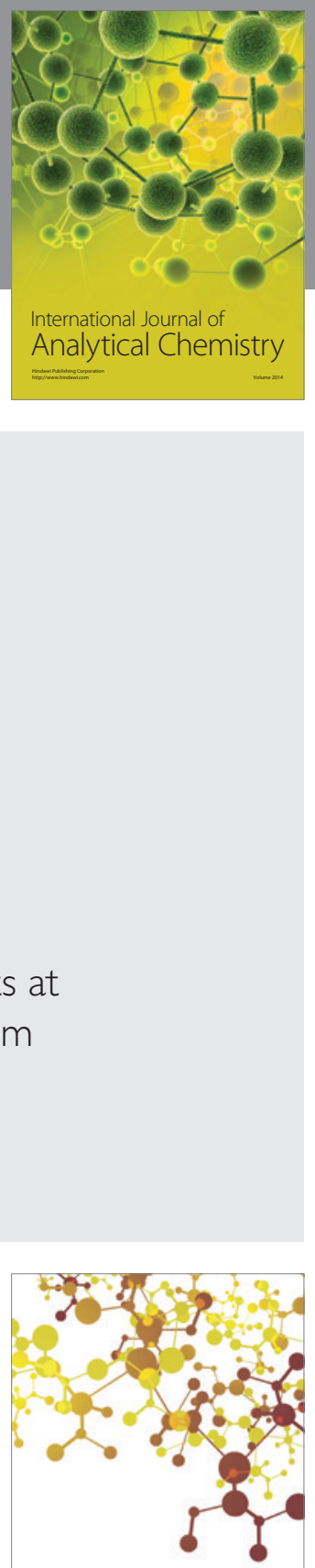

Journal of

Applied Chemistry
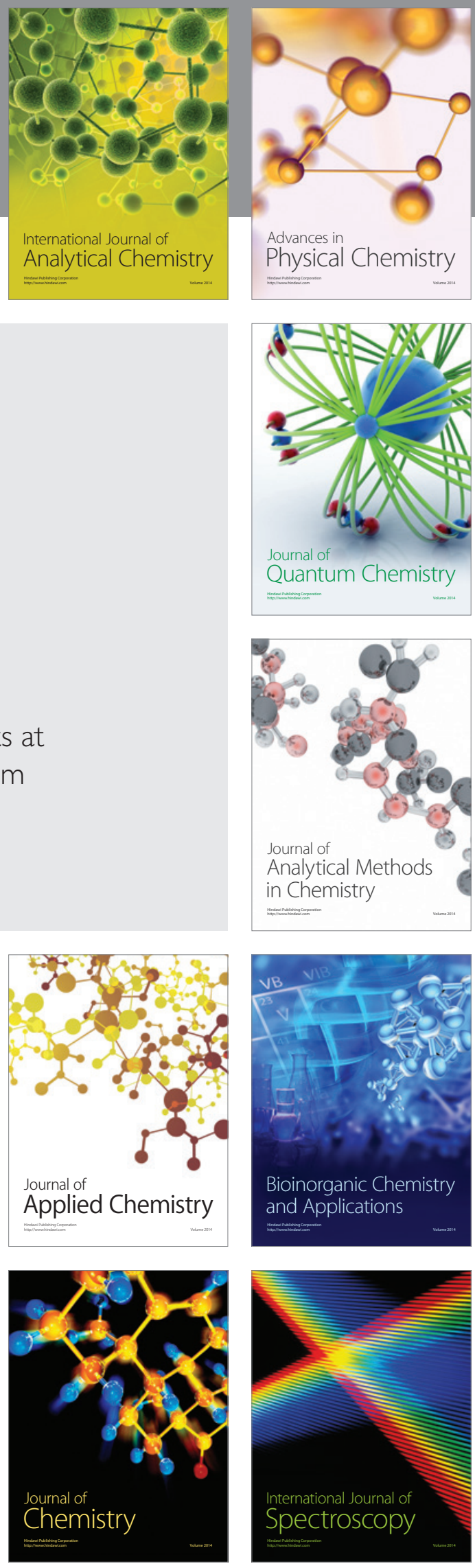